\title{
Estimation of Dietary Intake Concentration of Polycyclic Aromatic Hydrocarbon (PAH) Carcinogens from Tilapia zilli Commercially Available from Escravos River, Nigeria
}

\author{
Nworu Jerome Sunday ${ }^{1,2, *}$, Oti Wilberforce ${ }^{1}$, Enemose Edith Ajirioghene ${ }^{2}$ \\ ${ }^{1}$ Department of Industrial Chemistry, Faculty of Science, Ebonyi State University, Abakaliki, Nigeria \\ ${ }^{2}$ Department of Chemistry, School of Basic Science, Nigeria Maritime University, Okerenkoko, Delta State, Nigeria
}

Email address:

sunday.nworu@ebsu.edu.ng (N. J. Sunday)

${ }^{*}$ Corresponding author

\section{To cite this article:}

Nworu Jerome Sunday, Oti Wilberforce, Enemose Edith Ajirioghene. Estimation of Dietary Intake Concentration of Polycyclic Aromatic Hydrocarbon (PAH) Carcinogens from Tilapia zilli Commercially Available from Escravos River, Nigeria. American Journal of Applied Scientific Research. Vol. 5, No. 4, 2019, pp. 62-67. doi: 10.11648/j.ajasr.20190504.11

Received: October 24, 2019; Accepted: November 14, 2019; Published: November 25, 2019

\begin{abstract}
The Concentrations of Polycyclic Aromatic Hydrocarbons in the organs of a commonly consumed Tilapia zilli from Escravos River in Delta State, Nigeria were evaluated to ascertain the level of their bioaccumulation and the possible human health risks associated with their consumption. Samples were analysed with a Gas Chromatographic Flame Ionization Detector system and results were subjected to a one-way Analysis of Variance (ANOVA) to test for the significant level of the parameters across the groups. The level of significance was above $95 \%$ and the results were presented as mean \pm standard error. The values of PAHs reported followed different trends. The muscle had the highest average concentration ( $313.43 \pm 1.64$ $\mathrm{mg} / \mathrm{kg}$ ) followed by kidney $(266.72 \pm 0.36 \mathrm{mg} / \mathrm{kg})$ and the liver $(266.17 \pm 0.81 \mathrm{mg} / \mathrm{kg})$ while the gills had the lowest average concentration $(192.96 \pm 1.09 \mathrm{mg} / \mathrm{kg})$. The average concentrations of PAH reported in this research are highly above the EU recommended benchmark $(2 \mu \mathrm{g} / \mathrm{kg})$. The reported ailments from the communities cut across Escravos river could be traced to long term exposure of humans to these polycyclic aromatic hydrocarbons in the sea foods which are transferred into their food chain because of their high level of dependency for protein source.
\end{abstract}

Keywords: Dietary Intake, Total Petroleum Hydrocarbon, Total Aliphatic Hydrocarbon, Polycyclic Aromatic Hydrocarbon, Tilapia Zilli, Carcinogen, Escravos River

\section{Introduction}

Polycyclic aromatic hydrocarbons (PAHs) are organic compounds that are mostly colourless, white, or pale yellow solids. They are a ubiquitous group of several hundred chemically related compounds, environmentally persistent with various structures and varied toxicity. They have toxic effects on organisms through various actions. Generally, PAHs enter the environment through various routes and are usually found as a mixture containing two or more of these compounds, such as soot. Some polycyclic aromatic hydrocarbons are manufactured in the industry. The mechanism of toxicity is considered to be interference with the function of cellular membranes as well as with enzyme systems which are associated with the membrane. It has been proved that PAHs can cause carcinogenic and mutagenic effects and are potent immune-suppressants. Effects have been documented on immune system development, humoral immunity and on host resistance $[1,2]$. Polycyclic aromatic hydrocarbon (PAHs) can be formed both during biological processes and as products of incomplete combustion from either natural combustion sources (forest and brush fires) or man-made combustion sources (automobile emissions and cigarette smoke). Thus, PAHs are commonly detected in air, soil, and water [3].

Different types of tumour have also been induced with carcinogenic materials such as ethyl carbamate (urethanes), carbon tetrachloride and methyl benzanthracenes. The rapid growth in environmental industrialization around the Escravos communities has also caused discharge of solid and 
liquid wastes into the river. Fishes and other aquatic animals accumulates organic hydrocarbons and inorganic substances into their different organs from these pollution sites. This accumulation is a continuous process as aquatic animals that have lived longer accumulates higher proportions of these substances [2, 3].

Interactive section with young and aged people living along the Escravos river in kurutie/Okerenkoko have it that there have been several reported ailments which tend to be persistent over the years in the communities. These reported ailments include cancerous diseases, tumours, deafness, excessive skin diseases and many other mutagenic ailments [3]. These communities are bounded by the river and the major industrial process within the area is crude oil exploration. Crude oil spillage has been one of their adverse effects in the communities. The entire communities are highly remote and lack proper waste management processes. Generated wastes from the communities are discharged directly into the Escravos river, this is because they have limited land space for the waste disposal. Most of these wastes are highly poisonous and could bioaccumulate in the aquatic organisms over time. Fishing is the major occupation of the habitants. They process and consume these fishes in different ways. Most of these fishes, depending on their area of harvest are highly polluted. They highly bioaccumulate polycyclic aromatic hydrocarbons, aliphatic hydrocarbons and metals (trace and heavy). Their consumption must have been the major cause of the reported ailments from the communities. This research is aimed at quantitatively reporting the dietary intake of total petroleum hydrocarbons from the environment. The research work of [5] stated some human- mediated sources of petroleum products into the environment as oil production, marine transportation, atmospheric or aerial depositions from combustion of coal and gas flaring, direct ocean dumping, coastal, municipal and industrial wastes, and runoffs. This is the same situation in the Niger Delta region of Nigeria where exploration and production, transportation and storage of crude oil and in recent times, illegal crude oil refining and bunkering activities has caused substantial pollution along the coast lines, creeks, rivers and estuaries with huge depletion of the sources of livelihood of the people.

\section{Study Area}

The Escravos River is a river in southern Nigeria. "Escravos" is a Portuguese word meaning "slaves" and the area was one of the main conduits for slave trade between Nigeria and the United States in the 18th century. The length of the river is $57 \mathrm{~km}$ with its source from Niger river, having a link to Atlantic Ocean and Gulf of Guinea. It lies within the coordinate of Latitude: 5³4' 59.99" N Longitude: 509' 60.00" E [4].

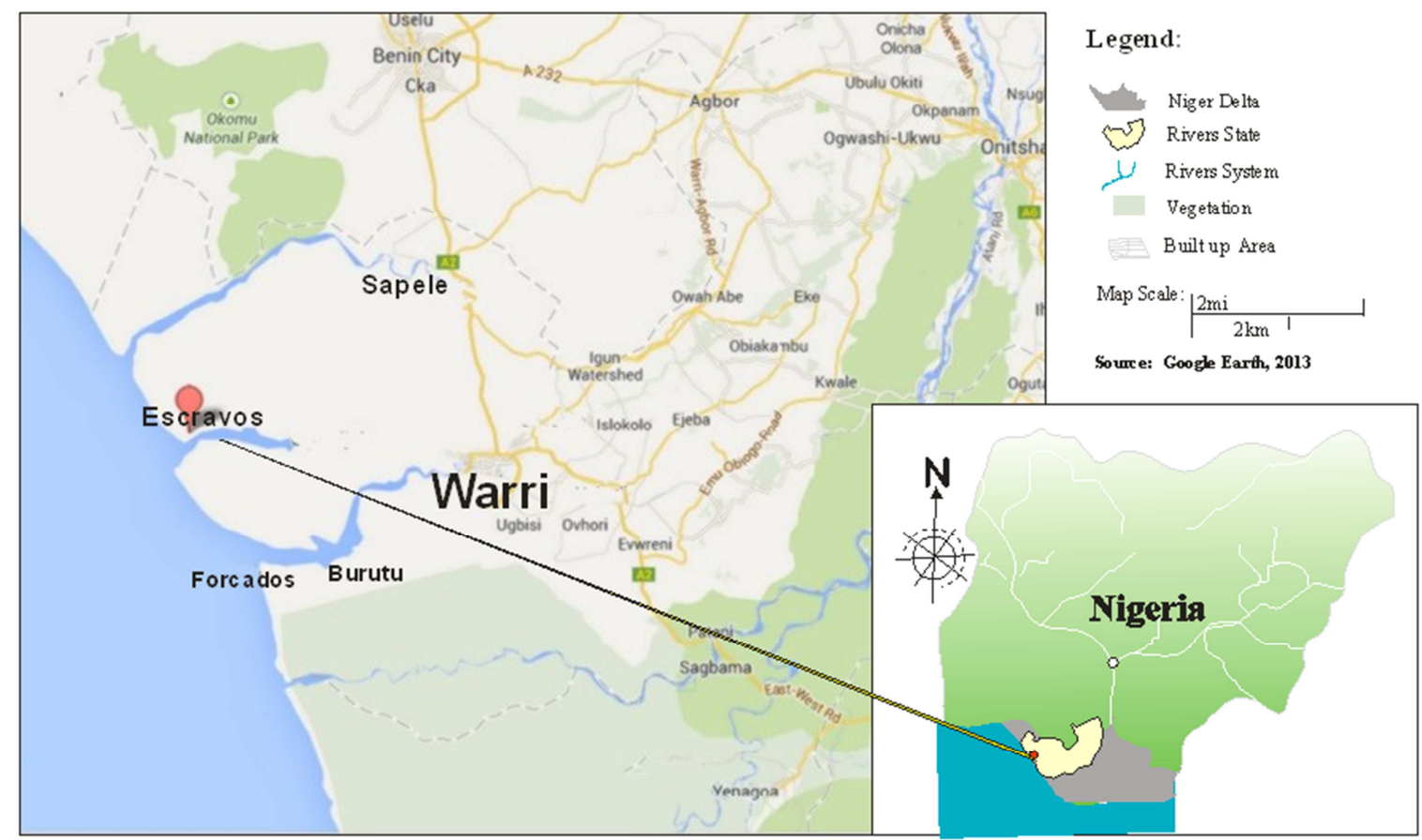

Figure 1. Map of Nigeria showing study area.

\subsection{Fish Sampling Method}

Tilapia fish species from Escravos River location were collected from local fisher men at the point of fishing, wrapped in a sterile aluminium foil, transported and stored at $-20^{\circ} \mathrm{C}$ until further analysis.

\subsection{Fish Sample Processing}

The fish samples were removed from refrigerator where it was stored, thawed and cleaned in tap water to remove any dirt. The thawed fishes were dissected using aseptic instrument and dishes and obtained the liver, gills, muscles, 
and kidney and were placed in a sample bottle and labelled for further analysis.

\section{Total Petroleum Hydrocarbons Extraction}

Fish samples were crushed with mortar and pestle. A $25 \mathrm{~g}$ aliquot of well crushed sample (Gill, Liver, Kidney and Muscle) were weighed into a clean $250 \mathrm{~mL}$ beaker. A mixture of solvent containing $50: 50 \mathrm{ml}$ of acetone and dichloromethane were prepared in a different beaker. $50 \mathrm{ml}$ of the solvent mixture was added into the beakers containing $10 \mathrm{~g}$ of each sample. To ensure high purity for consistent results, samples were spiked with $1 \mathrm{ml}$ of surrogate mixture. Samples were placed in a sonicator and agitated for 15 minutes at $70^{\circ} \mathrm{C}$. To obtain a clear extract, $10 \mathrm{~g}$ of anhydrous sodium sulphate were added. Extracts were separated from the mixture into a round bottom flask. This processes were repeated with additional $50 \mathrm{ml}$ of solvent mixture, sonicate and allowed the beaker to settle and decanted into the same round bottom flask. Extract were concentrated in rotary evaporator to $3 \mathrm{ml} \mathrm{[5].}$

\subsection{Column Preparation}

Columns were packed with $10 \mathrm{~g}$ of 100-200 mesh silica gel and glass fibre wool pre-conditioned (baked) at $105^{\circ} \mathrm{C}$ overnight. The column was made slurry by adding $10 \mathrm{ml}$ of $n-$ hexane [5].

\subsection{Fractionation and Re-concentration of Extracts}

Concentrated extracts were ready to be fractionated into aliphatic and aromatic fractions. This process was done in a column packed with a glass fibre wool and silica gel.
Fractionation of Polyaromatic Hydrocarbon was carried out in the prepared column by running dichloromethane (DCM) through the column containing the extract. This solvent DCM was used because it has affinity for PAHs. The fractionated sample of individual component was transferred into a round bottom-flask and concentrated into $2 \mathrm{ml}$. The concentrates were stored in a chromatographic vial ready for Polycyclic Aromatic Hydrocarbon analysis by GC FID 5890 SERIES II. The samples in the vial is were stored at $4^{\circ} \mathrm{C}$ prior to $\mathrm{GC}$ analysis $[1,5]$.

\subsection{Gas Chromatography Analysis}

Each extract transferred to a $1.5 \mathrm{ml}$ vial was loaded into a gas chromatography system GC FID 5890 SERIES II, with flame ionization detector (FID) and cold on-column injection. $1 \mu \mathrm{L}$ portion of the sample was injected and analysed for TPH (C8-C40). The analytical separation was carried out with a HP-5 column having the dimensions $30 \mathrm{~m}$ $\times 0.25 \mathrm{~mm}$ with a stationary phase thickness of $0.25 \mu \mathrm{m}$. The carrier gas was purified nitrogen held at a flow rate of $5 \mathrm{~mL} / \mathrm{min}$. The operating temperature was started at $60^{\circ} \mathrm{C}$ for $2 \mathrm{mins}$ and then increased at the rate of $10^{\circ} \mathrm{C} / \mathrm{min}$ to $300^{\circ} \mathrm{C}$ for $10 \mathrm{~min}$. The injector and detector temperature were maintained at $250^{\circ} \mathrm{C}$ and $300^{\circ} \mathrm{C}$ respectively. The minimum detection limit for all the compounds analysed was $0.1 \mu \mathrm{g} / \mathrm{kg}$ wet weight $[1,5]$.

\section{Statistical Analysis}

All data were subjected to one-way Analysis of Variance (ANOVA) using SPSS version 16 to test for the significant level of the parameters across the groups. The level of significance was chosen at $\mathrm{P}<0.05$ and the results were presented as mean \pm standard error.

Table 1. Mean \pm SE of Dietary intake (mg/kg body; weight/day) of Polycyclic Aromatic Hydrocarbon.

\begin{tabular}{|c|c|c|c|c|c|c|c|}
\hline Components & Muscle & Gill & Liver & Kidney & Min & Max & P-Value \\
\hline Naphthalene & $4.32 \pm 0.12$ & $3.06 \pm 0.11$ & $3.54 \pm 0.01$ & $7.36 \pm 0.05$ & 2.85 & 8.33 & $\mathrm{P}<0.05$ \\
\hline Acenaphthylene & $11.08 \pm 0.33$ & $3.86 \pm 0.25$ & $4.54 \pm 0.02$ & $4.26 \pm 0.14$ & 3.20 & 12.09 & $\mathrm{P}<0.05$ \\
\hline Acenaphthene & $7.70 \pm 0.14$ & $26.32 \pm 0.03$ & $15.34 \pm 0.12$ & $8.26 \pm 0.11$ & 7.52 & 26.77 & $\mathrm{P}<0.05$ \\
\hline Fluorene & $7.37 \pm 0.18$ & $2.96 \pm 0.15$ & $3.69 \pm 0.30$ & $4.65 \pm 0.25$ & 2.47 & 8.30 & $\mathrm{P}<0.05$ \\
\hline Phenanthrene & $3.98 \pm 0.02$ & $9.99 \pm 0.13$ & $8.14 \pm 0.12$ & $7.77 \pm 0.24$ & 3.42 & 10.23 & $\mathrm{P}<0.05$ \\
\hline Anthracene & $135.57 \pm 0.33$ & $85.12 \pm 0.01$ & $122.36 \pm 0.33$ & $129.39 \pm 0.18$ & 85.02 & 136.88 & $\mathrm{P}<0.05$ \\
\hline Fluoroanthene & $35.68 \pm 0.21$ & $7.58 \pm 0.11$ & $26.36 \pm 0.31$ & $13.26 \pm 0.22$ & 6.55 & 36.09 & $\mathrm{P}<0.05$ \\
\hline Pyrene & $16.51 \pm 0.33$ & $8.25 \pm 0.02$ & $8.87 \pm 0.05$ & $12.22 \pm 0.04$ & 8.25 & 17.87 & $\mathrm{P}<0.05$ \\
\hline Chrysene & $3.32 \pm 0.25$ & $6.15 \pm 0.14$ & $3.95 \pm 0.12$ & $8.69 \pm 0.13$ & 3.08 & 8.94 & $\mathrm{P}<0.05$ \\
\hline Benz (a) anthracene & $6.78 \pm 0.17$ & $2.69 \pm 0.54$ & $5.37 \pm 0.19$ & $4.23 \pm 0.08$ & 2.33 & 7.45 & $\mathrm{P}<0.05$ \\
\hline Benzo (b) fluoranthene & $3.76 \pm 0.24$ & $4.90 \pm 0.20 .16$ & $4.09 \pm 0.27$ & $5.64 \pm 0.17$ & 3.24 & 6.80 & $\mathrm{P}<0.05$ \\
\hline Benzo (k) fluoranthrene & $3.95 \pm 0.18$ & $3.76 \pm 0.18$ & $14.02 \pm 0.24$ & $12.08 \pm 0.31$ & 3.47 & 12.66 & $\mathrm{P}<0.05$ \\
\hline Benzo (a) pyrene & $20.95 \pm 0.32$ & $3.12 \pm 0.11$ & $7.14 \pm 0.08$ & $16.65 \pm 0.11$ & 2.85 & 21.12 & $\mathrm{P}<0.05$ \\
\hline Indeno $(1,2,3$-cd) pyrene & $36.33 \pm 0.44$ & $14.17 \pm 0.30$ & $24.56 \pm 0.15$ & $18.21 \pm 0.36$ & 13.18 & 38.02 & $\mathrm{P}<0.05$ \\
\hline Dibenz $(\mathrm{a}, \mathrm{h})$ anthracene & $8.94 \pm 0.14$ & $6.08 \pm 0.22$ & $6.23 \pm 0.11$ & $7.09 \pm 0.09$ & 5.54 & 9.30 & $\mathrm{P}<0.05$ \\
\hline Benzo $(g, h, i)$ perylene & $7.10 \pm 0.17$ & $4.90 \pm 0.05$ & $7.89 \pm 0.01$ & $6.88 \pm 0.05$ & 4.80 & 7.95 & $\mathrm{P}<0.05$ \\
\hline Total PAH (mg/kg) & $313.43 \pm 0.67$ & $192.96 \pm 0.45$ & $266.17 \pm 0.81$ & $266.72 \pm 0.36$ & 192.96 & 318.02 & $\mathrm{P}<0.05$ \\
\hline
\end{tabular}




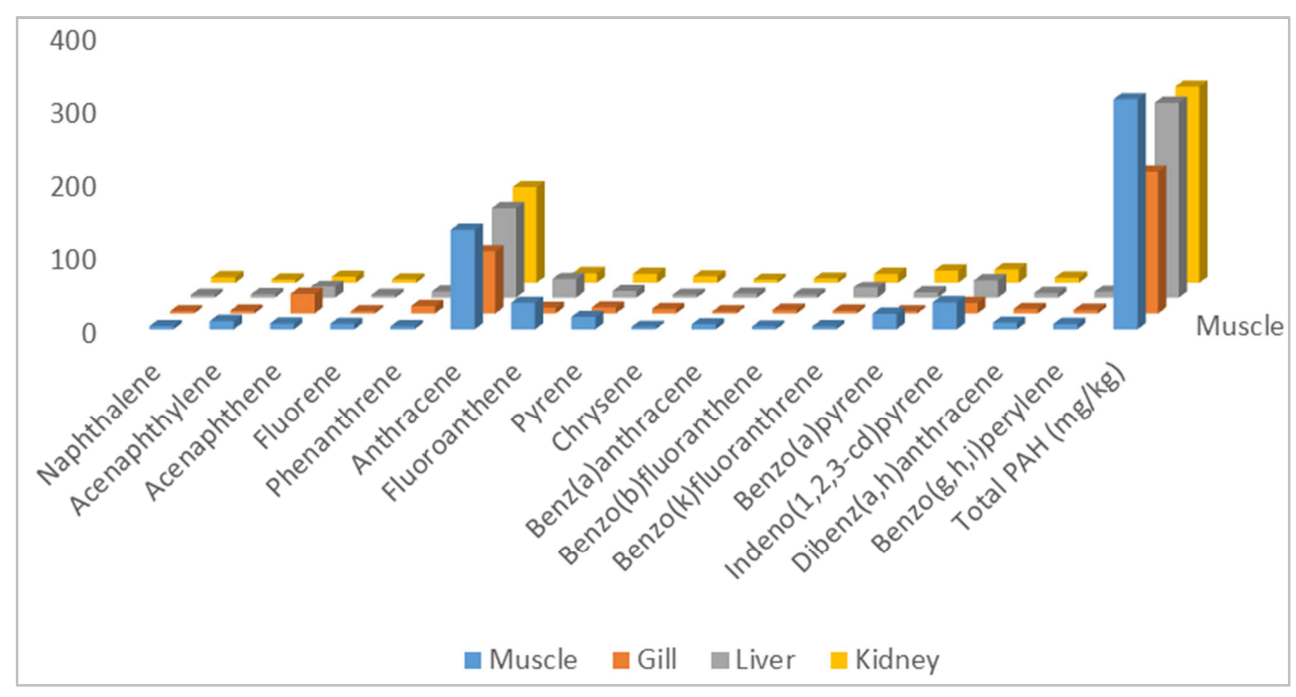

Figure 2. Polynuclear Aromatic Hydrocarbon Content (mg/kg).

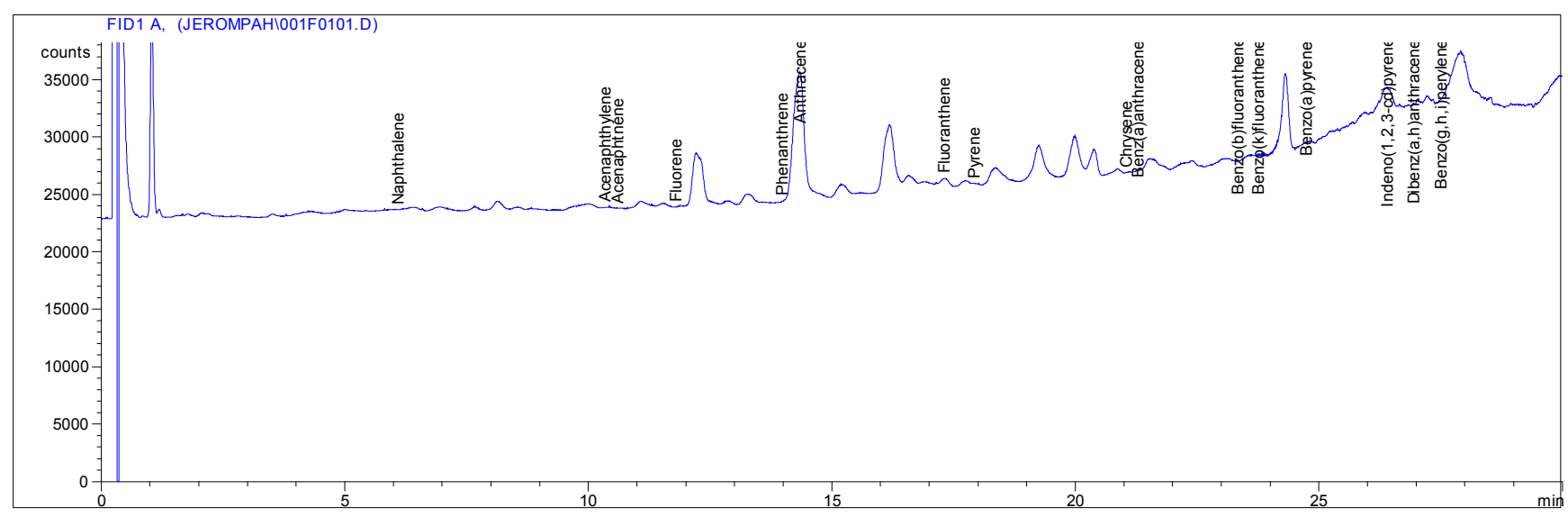

Figure 3. Chromatogram for the Polycyclic Aromatic Hydrocarbons from the muscles of the tilapia zilli.

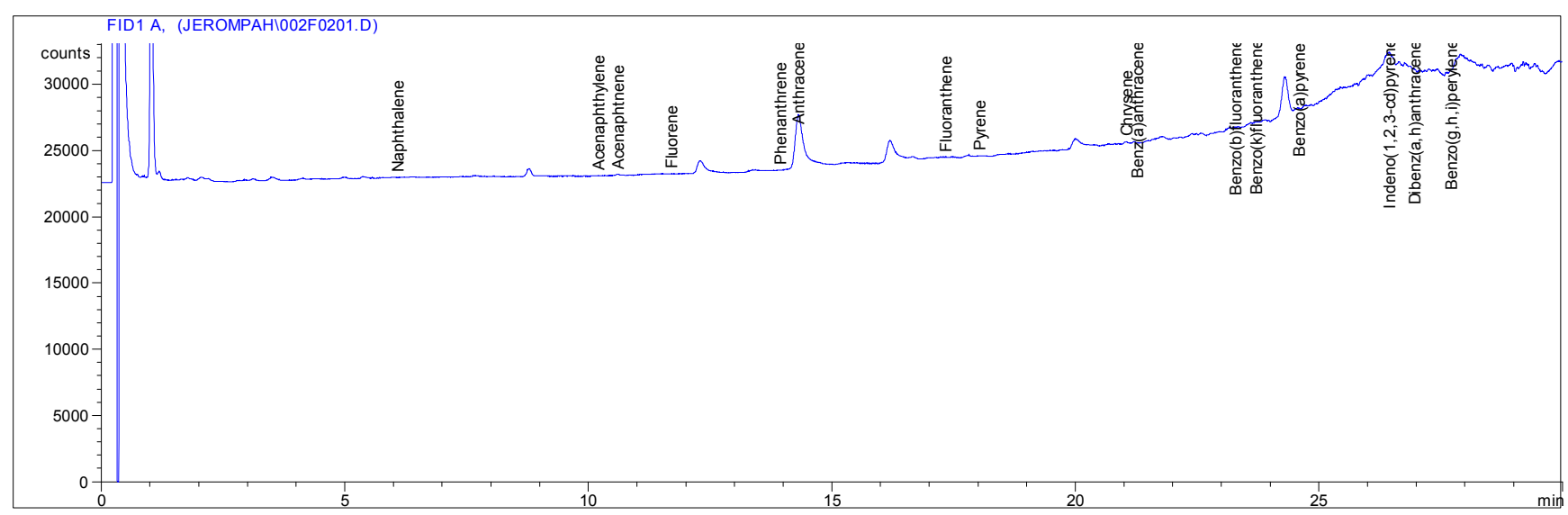

Figure 4. Chromatogram for the Polycyclic Aromatic Hydrocarbons from the Gills of the tilapia zilli.

\section{Discussion}

Table 1 and figure 2 represent the Mean \pm Standard error of Polycyclic Aromatic Hydrocarbon component from organs of tilapia fish $(\mathrm{mg} / \mathrm{kg})$. Figures 3 and 4 represent the chromatograms of polycyclic aromatic hydrocarbons from the muscle and gill of tilapia zilli. In this research, sixteen components of aromatics which makes up the PAH's has been analysed. Polycyclic aromatic hydrocarbons (PAHs) are ubiquitous anthropogenic pollutants that can be biologically amplified to high concentrations in food webs. Due to their lipophilicity, persistence, and high toxicity, these residues are readily accumulated in the tissues of non-target living organisms where they may cause detrimental effects. PAHs are toxic, carcinogenic, and mutagenic to all organisms, including humans $[6,7]$. The metabolites of PAHs may bind 
to proteins and DNA, which causes biochemical disruption and cell damage in animals and cancer in human [7].

Naphthalene, Acenaphthylene, Acenaphthene, Fluorene, Anthracene, Fluoranthene and Pyrene are less carcinogenic, while benzo (a) anthracene, chrysene, benzo (k) fluoranthene, benzo (a) pyrene, benzo (b) fluoranthene, indeno $(1,2,3)$ perylene, dibenzo $(\mathrm{a}, \mathrm{h})$ anthracene and benzo $(\mathrm{g}, \mathrm{h}, \mathrm{i})$ perylene are highly carcinogenic [8].

For the PAH, the maximum and minimum concentrations of naphthalene are 8.33 and $2.85 \mathrm{mg} / \mathrm{kg}$ respectively. Highest average bioaccumulation was recorded in the kidney of the tilapia fish as $7.36 \pm 0.05 \mathrm{mg} / \mathrm{kg}$ while the gills recorded the least value of $3.06 \pm 0.11 \mathrm{mg} / \mathrm{kg}$. Acenaphthylene and acenaphthene minimum bioaccumulation across the organs are 3.20 and $7.52 \mathrm{mg} / \mathrm{kg}$ respectively while their maximum concentrations are 12.09 and $26.77 \mathrm{mg} / \mathrm{kg}$ respectively. The highest average concentration of acenaphthylene and acenaphthene were observed in the muscles $(11.08 \pm 0.33$ $\mathrm{mg} / \mathrm{kg})$ and gills $(26.32 \pm 0.03 \mathrm{mg} / \mathrm{kg})$ of the tilapia fish respectively, while their lowest mean concentrations were recorded in the gills $(3.86 \pm 0.25 \mathrm{mg} / \mathrm{kg})$ and the muscles $(7.70 \pm 0.14 \mathrm{mg} / \mathrm{kg})$ of the tilapia fish respectively. The PAH stated here are far higher than the values reported by [9] in the investigation from four species of fish at Degele Community, Nigeria. The high mean concentrations recorded in the gills and muscles are similar to the fact that they have direct interaction with the contaminated medium, thereby ingesting higher concentrations.

The minimum concentrations of Fluorene, Phenanthrene, Anthracene, Fluoroanthene, Pyrene and Chrysene are 2.47, $3.42,85.02,6.55,8.25$ and $3.08 \mathrm{mg} / \mathrm{kg}$ while their maximum concentrations are $8.30,10.23,136.88,36.09,17.87$ and 8.94 $\mathrm{mg} / \mathrm{kg}$ respectively. Anthracene showed a very high mean concentration across the organs. The muscle concentration is as high as $135.57 \pm 0.33 \mathrm{mg} / \mathrm{kg}$ while the gill recorded $85.12 \pm 0.01 \mathrm{mg} / \mathrm{kg}$. Anthracene when consumed targets the human skin, blood, intestines, blood and the lymph system. Exposure to high doses of anthracene for a short time can cause skin damage. It can also cause itching, burning and edema, a build-up of fluid in tissues. Humans exposed to anthracene experiences headache, loss of appetite, nausea, swelling or inflammation of the stomach and intestines. Anthracene has also been recorded to have caused tumours in laboratory animals that were exposed to anthracene, through their foods, breathing from contaminated air and direct skin application $[10,11]$.

The minimum concentrations of benzo (a) anthracene, benzo (b) fluoranthene, benzo (k) fluoranthrene and benzo (a) pyrene are $2.33,3.24,3.47$ and $2.85 \mathrm{mg} / \mathrm{kg}$ respectively while their maximum concentrations are $7.45,6.80,12.66$ and $21.12 \mathrm{mg} / \mathrm{kg}$ respectively. In a report of [11], when a pregnant mice were fed with high doses of PAH (benzo (a) pyrene) they experienced reproductive problems. The offspring of the pregnant mice showed birth defects and a decrease in their body weight. The animal study reported that exposure of mice to $308 \mathrm{ppm}$ of PAH (benzo (a) pyrene) in food for 10 days (short term exposure) caused birth defects of the offspring, while mice exposed to 923 ppm of benzo (a) pyrene in food for months caused liver and blood problems.

The minimum concentrations of indeno (1, 2, 3-cd) pyrene, Dibenz $(\mathrm{a}, \mathrm{h})$ anthracene and benzo $(\mathrm{g}, \mathrm{h}, \mathrm{i})$ perylene are $13.18,5.54$ and $4.80 \mathrm{mg} / \mathrm{kg}$ respectively while their maximum concentrations are 38.02, 9.30 and $7.95 \mathrm{mg} / \mathrm{kg}$ respectively. Biological monitoring of exposure to PAHs is of primary interest, due to the widespread diffusion of these compounds and to their toxicological relevance. However, the health effects of individual PAHs are not exactly alike. In fact, the International Agency for Research on Cancer classifies some PAHs as known, possibly, or probably carcinogenic to humans (Group 1, 2A or 2B). Among these are benzo [a] pyrene (Group 1), naphthalene, chrysene, benz [a] anthracene, benzo [k] fluoranthene and benzo [b] fluoranthene (Group 2B) [12, 13]. Some PAHs are well known as carcinogens, mutagens, and teratogens and therefore pose a serious threat to the health and the wellbeing of humans. The most significant health effect to be expected from inhalation exposure to PAHs is an excess risk of lung cancer [13].

\section{Conclusion}

From this research, it is very evident that Escravos river across Kurutie/Okerenkoko in Delta State is highly polluted with substances containing large amount of polycyclic aromatic hydrocarbons. Fishes in the river accumulates large quantity of them over time. The polycyclic aromatic hydrocarbons are carcinogenic and could be of health challenge over time. Naphthalene, Acenaphthylene, Acenaphthene, Fluorene, Anthracene, Fluoranthene and Pyrene are less carcinogenic, while benzo (a) anthracene, chrysene, benzo (k) fluoranthene, benzo (a) pyrene, benzo (b) fluoranthene, indeno $(1,2,3)$ perylene, dibenzo $(\mathrm{a}, \mathrm{h})$ anthracene and benzo (g, h, i) perylene are highly carcinogenic. The tilapia fish analysed accumulated high concentration of aromatic hydrocarbon. Most aromatic hydrocarbon has no trace of carcinogenicity, but their presence in environment elevates the effects of polycyclic aromatic hydrocarbon which have proven to be carcinogenic. The muscle had the highest average concentration of PAHs while the gills had the lowest average concentration. The results showed that the organs studied are good bioaccumulators. This study therefore revealed that, there are substantial exposure and bioaccumulation in the commonly consumed tilapia fish species in Kurutie/Okerenkoko from Escravos river, and there could be possible human risk to cancer and other related health challenges.

\section{Recommendations}

The study area is highly polluted; it will be of environmental interest if an environmental impact assessment is properly conducted in the villages across Escravos river. This process should be a continuous program to ensure proper check in the environment and establish a baseline for 
subsequent studies. Further research on the individual PAH carcinogenic potencies, carcinogenic toxic equivalence, excess cancer risk, PAH index and the screening values in PAH on fishes from Escravos river should also be carried out. It will also be of huge benefit to the remediation of the environment if the residences of the affected communities are provided with alternative means of waste disposal as they continuously complain that they have no other alternative to dispose their generated wastes other than the Escravos river.

\section{Acknowledgements}

My gratitude goes to Dr Wilberforce Oti for his commitment and analytical reasoning that brought this work to completion. My acknowledgement also goes to all staff and management of DUKORIA laboratory for their contributions and opportunities to access their equipment for analysis. To Captain James Mughenbofa, thanks for taking me around the Escravos River and providing your equipment for sampling. To my colleagues in office, Dr Edith Enemose, Onyema Henry, and Edisson Igho Oghonyon thanks for your morale support.

\section{Conflict of Interest}

Both authors declare that there is no competing interest with regard to this work. We hereby declare that the originality of this work for publication is to the best knowledge of the authors.

\section{References}

[1] Anyakora, C. and Coke, H. (2006). Assessment of Polycycloc Aromatic Hydrocarbon Content in four Species of Fish in the Niger Delta by GC/MS. MSAS'. American Journal of Environmental Science, 4: 152-164.

[2] CCME (Canadian Council of Ministers of the Environment). (2010). Canadian Soil Quality Guidelines for Potentially Carcinogenic and other PAHs: Scientific Criteria Document. CCME: Winnipeg: 214p.

[3] Anyakora, C., Ogbeche, K. A., Uyimadu, J., Olayinka, K., Alani, R. A., and, Alo, B. I. (2004). Determination of
Polynuclear Aromatic Hydrocarbons in Water Sample of the Lagos lagoon. The Nigerian Journal of Pharmacy, 35: 53-89.

[4] Ibitola, M. P. (2009). The Hydrodynamic Fluxes of the Escravos and Forcados Rivers: Implications for Transport and Circulation Patterns off the Western Niger Delta. 22-41.

[5] Schwab, A. P; Su, J., Wetze, L. S; Pekarek, S. and Banks, M. K. (1999). Extraction of Petroleum Hydrocarbons from Soil by Mechanical Shaking. Environmental and Hydraulic Engineering, 33: 1940-1945.

[6] Nacci, D. E.; Kohan, M. P and George, E. (2002). "Effects of Benzo [a] pyrene Exposure on a Fish Population Resistant to the Toxic Effects of Dioxin-like Compounds," Aquatic Toxicology. 57 (4): 203-215.

[7] Armstrong, B.; Hutchinson, E., Unwin, J and Fletcher, T. (2004). "Lung Cancer Risk after Exposure to Polycyclic Aromatic Hydrocarbons: A Review and Meta-Analysis," Environmental Health Perspectives. 112 (9): 970-978.

[8] US Environmental Protection Agency (USEPA) (1993). Provisional Guidance for Quantitative Risk Assessment of Polycyclic Aromatic Hydrocarbons. 4 (3): 24-54.

[9] Olaji, E. D., Nwogu, N. A., Yakubu, A. F. and Olaji, C. O. (2014). Assessment of Total Hydrocarbon Concentration in Four Fish Species of Degele Community, Nigeria and Their Dietary Intake in the Populace. Advances in Research 2 (2): 109-118.

[10] Boehm, P. D., Page, D. S., Brown, J. S., Neff, J. M., Bragg, J. R. and Atlas R. M. (2008). Distribution and Weathering of Crude Oil Residues on Shorelines 18 Years After the Exxon Valdez Spill. Environmental Science and Technology, 42 (24): 9210-9216.

[11] Faust, R. A., (1991). Oak Ridge National Laboratory, Chemical Hazard Evaluation Group. Toxicity Summary for Anthracene. 38-44.

[12] Mohanraj, R., Dhanakumar, S. and Solaraj, G. (2012). Polycyclic aromatic hydrocarbons bound to PM2.5 in urban Coimbatore, India with emphasis on source apportionment. Sci World J, 12 (4): 312-320.

[13] EPRI (Electric Power Research Institute). (2000). Literature Review of Background Polycyclic Aromatic Hydrocarbons. Final report; 2 (1): 15-24. 